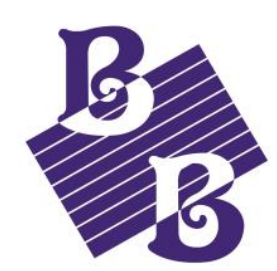

BioBacta

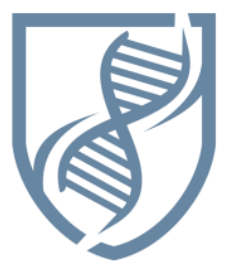

Journal of Bioscience and Applied Research www.jbaar.org

\title{
An abundance of soil invertebrates in young and mature palm oil plot in relations to soil physical properties: A preliminary study
}

\author{
Nurul Hazirah Hamzah ${ }^{1}$, Abrar Maqtan', Hishamuddin Omar'1, and Hafiz Ibrahim1 \\ ${ }^{1}$ Department of Biology, Faculty of Science, Universiti Putra Malaysia, UPM, Serdang, Selangor 43400, Malaysia \\ (email: nurulhazirahhamzah@gmail.com)
}

\begin{abstract}
The soil biota is considered the biological engine of the earth and is associated with most of the critical functions of the soil in terms of ecosystem services. The knowledge on the impact of land management and agricultural activities on the abundance and diversity of soil invertebrates is still understudied especially in Malaysia. This study was conducted to investigate the relation of the abundance and diversity of soil invertebrates with the soil physical parameters from two different palm oil plots. Sampling methods of soil invertebrates include pitfall trap and Berlese-Tullgren funnel. Invertebrate's abundance and diversity were measured and invertebrates were identified according to their morphological characteristics under the dissecting microscope concerning taxonomic keys. A total of 621 individuals were documented from both sites with 408 collected in mature palm oil farms whereas 213 individuals were documented in young palm oil farms. Hymenoptera $(67.31 \%)$ is the most dominant invertebrate followed by Orthoptera $(12.40 \%)$ and Arachnida (10.14 \%). Morphospecies diversity, evenness, and richness are highest in mature palm oil plot with Shannon; 1.54, Evenness; 0.32, and Menhinick; 0.67 respectively. Well-developed canopy, plenty of shelters, and reduced agricultural activities in mature palm oil mainly contributed to ideal soil physical parameters (bulk density; $1.23\left(\mathrm{~g} / \mathrm{cm}^{3}\right) \pm 0.02$, porosity; $55.03 \% \pm 2.48$, temperature; $35.65^{\circ} \mathrm{C} \pm 0.30$ and moisture; $34.05 \% \pm 0.60$ ) produces a comparatively more balanced habitat for a diverse community of soil invertebrates. Because of the roles they play in soil biological processes, soil invertebrates may be used as bioindicators of soil health. This study can be used as a baseline for more extensive research that may be applied in future planning on land management in achieving the nation's agricultural sustainability.
\end{abstract}

Keywords: agricultural sustainability; ecosystem services; land management; soil invertebrates

\section{Introduction}

The production of palm oil is a significant industry across the tropical regions, particularly in Southeast Asia, and is currently growing in Africa and the Neotropics (Wich et al., 2014). This development is gaining concerns due to the decline of many taxonomic groups (Savilaakso et al., 2014) and ecosystem roles (Barnes et al., 2014) which has resulted from the transformation of natural forests to oil palm farms. One of the major threats to the conservation of biodiversity in Southeast Asia includes the transformation of natural forest to oil palm estates which have resulted in a reduction of both species' abundance and richness as well as a significant decrease in forest species (Foster et al., 2011). 
Various land uses and soil management impacted the quality of the soil and the sustainability of the agricultural production systems. Soil tillage activities such as plowing and disking in the tropical areas have reduced soil organic material and intensified soil erosion resulting in physical, chemical, and biological alterations in the soil features. This will increase the reliance on external processes and therefore escalate production costs, resulting in environmental effects. Nevertheless, the more environmentally friendly cropping processes such as no-tillage and organic agricultural practices are more dependent on the biological system for survivability (Kaschuk et al., 2010). Both natural and agricultural sustainable ecosystems depend on the flow of nutrients across feeding levels, which are primarily transitioned by soil invertebrates and microorganisms (Chen et al., 2003).

The soil microbial community and fauna are regarded as vital in any ecosystem as they act on the soil organic material decomposition, nutrient cycling, and influencing the soil physical and chemical quality, with direct impacts on soil fertility. That is why edaphic fauna are excellent indicators of soil health, particularly if the indicator responds to ecological activities happening in the soil. The biological aspect of agricultural soil is often neglected as the emphasis is directed more towards the physical and chemical attributes of soil. One of the most overlooked components of the oil palm plantation is the soil habitat and the biodiversity within it. It is hard to deny those allegations without providing scientific data on biodiversity and the habitat of oil palm plantations. Presently, there is a pioneering movement to study the biological aspect of soil particularly through organic farming. However, in Malaysia, there are no serious reports on soil biodiversity and its role in crop production. To begin adding more baseline information on this situation, this study was conducted to determine the abundance and diversity of soil invertebrates in mature and young palm oil plantations. Physical soil parameters, canopy structure, and soil cover were also taken into account to determine its influence on soil invertebrates' abundance and diversity.

\section{Materials and Method}

\subsection{Study area}

The study was conducted in Universiti Putra Malaysia (UPM), Serdang, Selangor, Malaysia. Samples were collected in March-December 2018. The sites were located at palm oil farm $\left(2^{\circ} 59^{\prime} 12.0^{\prime \prime} \mathrm{N}\right.$ $\left.101^{\circ} 43^{\prime} 25.0^{\prime \prime E}\right)$ at Taman Pertanian Universiti (TPU)
(=University Agricultural Park). The mature (15-20 years old) and young palm oil plot (2-3 years old) were separated by an 80 -meter gap. The climate in the region is tropical with an average temperature of 26.9 ${ }^{\circ} \mathrm{C}$ and an average annual rainfall of $2369 \mathrm{~mm}$ (Climate-Data.org, 2019).

\subsection{Procedures}

Sampling of soil invertebrates was carried out using two different methods which were pitfall traps (Neto et al., 2011) for highly mobile organisms within each of the plots and Berlese-Tullgren funnels to separate invertebrates from collected soil samples. In each sampling plot, a quadrant $(15 \times 15 \mathrm{~m})$ was applied and divided into 9 subplots $(5 \times 5 \mathrm{~m})$. The distance between traps was 5 meters (Maqtan et al., 2018). In the pitfall trap method, the plastic traps were buried in the ground with diluted dishwasher liquid (approx. $15 \mathrm{ml}$ ). Samples were collected from traps after being left for 24 hours and taken to the laboratory where the captured invertebrates were washed using distilled water then stored in $70 \%$ alcohol for the preservation of the morphological form of the soil invertebrates (Sahu, 2015). For the Berlese-Tullgren funnel, nine soil core samples $(5 \mathrm{~cm}$ depth) were obtained randomly from each plot to collect soil invertebrates which were then placed in Berlese funnels (Çakır and Makineci, 2018; Maqtan et al., 2018). Collected soil samples were homogenized by hand in a bucket. Information (location and date) of soil sample was recorded then taken to the lab by using an ice bag cooler.

\subsection{Soil invertebrate's identification}

Collected invertebrates were then classified to the nearest possible taxonomic level using dissecting microscope. This is done by employing morphologically-based designation based on the dichotomous key classification (Thyssen, 2010). Documentation of abundance in each sample was conducted by summing up the total number for each morphospecies, in the laboratory of plant physiology, Faculty of Science, UPM.

\subsection{Data analysis}

\subsubsection{Taxonomic groups}

Findings of the invertebrate community were documented for each soil sample, as relative 
abundance (i.e., individual number of each taxon) (Santorufo et al., 2012) and percentage composition.

\subsubsection{Biological indices}

Invertebrates' diversity was measured using diversity indices namely Shannon (H'), Evenness (E), and Menhinick (R) by using PAST 3.0 (Paleontological Statistics) software.

Materials and methods must include study design, methods used along with references, and statistical information. It must be enough to allow experiments to be reproduced. Any previously published research work can also be cited and notification should be mentioned clearly.

\section{Species diversity}

Calculation of species diversity was done by using the Shannon Diversity Index (Shannon and Wiener, 1949) Data were inserted into the spreadsheet that could be set up to calculate the diversity index automatically.

$$
H^{\prime}=-\sum_{i=1}^{S} p_{i} \log _{2} p_{i}
$$

Where:

$$
\begin{aligned}
& \mathrm{S}=\text { Total number of species } \\
& \mathrm{I}=\text { Number assigned to the species } \\
& \text { p_i = Proportional abundance of the ith } \\
& \text { species (Shannon-Wiener, 1949) }
\end{aligned}
$$

\section{Evenness}

Evenness is strictly associated with the species diversity and signifies equality of the populations analytically. The less variation in populations between the species, the higher the evenness value is acquired.

$$
\mathrm{E}=\frac{H^{I}}{H I \max }
$$

Where:

$H^{\prime}=$ Number derived from the Shannon diversity index

$\mathrm{H}^{\prime} \max =\mathrm{s}$ the maximum possible value of $\mathrm{H}^{\prime}$

\section{Species richness}

Species richness directly attributes to the number of species in the community. Ludwig and Reynolds (1988) proposed two widely known indices to be used as richness measures which are the Margalef and Menhinick index. Menhinick's index (Whittaker, 1977) is calculated as follows:

$$
\mathrm{D}_{\mathrm{Mn}}=\frac{\mathrm{s}}{\sqrt{\mathrm{N}}}
$$

Where:

$$
\begin{aligned}
& \mathrm{S}=\text { number of species recorded } \\
& \mathrm{N}=\text { total number of individuals over all } \mathrm{S} \\
& \text { species }
\end{aligned}
$$

\subsubsection{Statistical analysis.}

Statistical analysis was conducted with IBM SPSS statistics version 20. Data of invertebrates after normality test were tested using t-test and a value of $\mathrm{P}$ $\leqslant 0.05$ was recognized to be the level of statistical significance. Pearson correlation test was applied to correlate between soil physical parameters and abundance of soil invertebrates morphospecies.

\section{Results}

\subsection{Taxonomic groups}

A total of 621 individuals were collected comprising of 16 morphospecies during the sampling period (Table 1). Between the two study locations, the mature palm oil plot recorded the greatest abundance of individuals with a total of 408 individuals while the young palm oil plot recorded a total number of 213 individuals. Hymenoptera recorded the greatest number of individuals (418 individuals) collected with a percentage composition of $62.99 \%$ and $75.59 \%$ in mature and young palm oil plots respectively. This was followed by Orthoptera (77 individuals) with a percentage composition of $12.99 \%$ in mature palm oil plot and $11.27 \%$ in the young palm oil plot. Arachnida (63 individuals) recorded a percentage composition of $11.03 \%$ in mature palm oil plot whereas, in young palm oil plot, it recorded a percentage composition of $8.45 \%$.

Based on t-test, there were significant difference between study sites of Annelida ( $\mathrm{P}=0.016)$, Blattodea $(\mathrm{P}=0.05)$, Coleoptera $(\mathrm{P}=0.027)$, Diptera $(\mathrm{P}=0.016)$, Ephemerida $(\mathrm{P}=0.016)$, Geophilomorpha $(\mathrm{P}=0.0 .16)$, Hemiptera $(\mathrm{P}=0.016)$ and Lepidoptera $(\mathrm{P}=0.016)$. There was no significant difference between other 
morphospecies of invertebrates (Table 2). The t-test also suggested that there was no significant difference between study sites for all soil physical parameters and diversity indices (Table 3).

\subsection{Invertebrates diversity}

The result indicated that the Shannon diversity of the mature palm oil plot is greater than the young palm oil plot as the diversity index $\left(\mathrm{H}^{\prime}\right.$ value) was higher (0.54) for the mature palm oil plot than that of the young palm oil plot (0.42) (Table3). The prominent taxa in mature palm oil plots include Hymenoptera (62.99\%), Odonata (12.99\%), and Arachnida (11.03\%). Additionally, a mature palm oil plot also recorded greater Evenness and Menhinick index compared to a young palm oil plot with values $\mathrm{E}=1.36$ and $\mathrm{DMn}=1.29$ respectively.

Both communities were relatively even according to Pielou's equitability index (J'), which was close to 1 .

Table 1: Abundance and percentage composition of soil invertebrates collected by traps and funnels from study sites

\begin{tabular}{|c|c|c|c|c|c|c|c|c|c|}
\hline \multirow[b]{2}{*}{ Morphospecies } & \multicolumn{4}{|c|}{ Mature palm oil plot } & \multicolumn{4}{|c|}{ Young palm oil plot } & \multirow{2}{*}{$\begin{array}{c}\text { Grand } \\
\text { total }\end{array}$} \\
\hline & Trap & Funnel & Total & $\begin{array}{c}\text { Percentage } \\
(\%)\end{array}$ & Trap & Funnel & Total & $\begin{array}{c}\text { Percentage } \\
(\%)\end{array}$ & \\
\hline Annelida & 1 & $* \mathrm{NF}$ & 1 & 0.25 & NF & $\mathrm{NF}$ & $\mathrm{NF}$ & - & 1 \\
\hline Arachnida & 36 & 9 & 45 & 11.03 & 13 & 5 & 18 & 8.45 & 63 \\
\hline Blattodea & 3 & 1 & 4 & 0.98 & NF & $\mathrm{NF}$ & $\mathrm{NF}$ & - & 4 \\
\hline Coleoptera & 18 & 6 & 24 & 5.88 & 1 & NF & 1 & 0.47 & 25 \\
\hline Diplura & 2 & NF & 2 & 0.49 & 1 & NF & 1 & 0.47 & 3 \\
\hline Diptera & 3 & NF & 3 & 0.74 & NF & NF & $\mathrm{NF}$ & - & 3 \\
\hline Ephemerida & 3 & 2 & 5 & 1.23 & NF & $\mathrm{NF}$ & $\mathrm{NF}$ & - & 5 \\
\hline Geophilomorpha & 2 & NF & 2 & 0.49 & $\mathrm{NF}$ & $\mathrm{NF}$ & $\mathrm{NF}$ & - & 2 \\
\hline Hemiptera & 2 & NF & 2 & 0.49 & NF & $\mathrm{NF}$ & NF & - & 2 \\
\hline Hymenoptera & 189 & 68 & 257 & 62.99 & 114 & 47 & 161 & 75.59 & 418 \\
\hline Lepidoptera & 1 & NF & 1 & 0.25 & NF & $\mathrm{NF}$ & $\mathrm{NF}$ & - & 1 \\
\hline Isopoda & 3 & 1 & 4 & 0.98 & 3 & 3 & 6 & 2.82 & 10 \\
\hline Odonata & 2 & NF & 2 & 0.49 & NF & $\mathrm{NF}$ & NF & - & 2 \\
\hline Orthoptera & 32 & 21 & 53 & 12.99 & 17 & 7 & 24 & 11.27 & 77 \\
\hline Thysanoptera & 1 & NF & 1 & 0.25 & 1 & NF & 1 & 0.47 & 2 \\
\hline Trichoptera & 2 & NF & 2 & 0.49 & 1 & NF & 1 & 0.47 & 3 \\
\hline Total & 300 & 108 & 408 & - & 151 & 62 & 213 & - & 621 \\
\hline
\end{tabular}

*NF=not found
Based on the Pearson correlation test (Table 4), there was a positive correlation between bulk density and abundance of Diplura (0.66), Hymenoptera (0.62), and Isopoda (0.98) in mature palm oil plot. Findings also showed that there was a positive correlation between bulk density and abundance of Arachnida (0.97), Hymenoptera (0.61), and Thysanoptera (0.90) in the young palm oil plot. Furthermore, soil porosity recorded a positive correlation with the abundance of Arachnida (0.63) and Hymenoptera (0.98) in mature palm oil plot whereas, in young palm oil plot, it recorded a strong positive correlation with the abundance of Arachnida (0.96), Hymenoptera (0.85) and Thysanoptera (0.69). Also, soil temperature documented a positive correlation with the abundance of Blattodea (0.73), Coleoptera (0.84), Diplura (0.81), Diptera (0.92), and Ephemerida (0.92) while in young palm oil plot, it recorded a positive correlation with the abundance of Arachnida (0.69) and Thysanoptera (0.96). Lastly, there was a strong positive correlation between soil moisture and abundance of Arachnida (0.90), Hymenoptera (0.82) and Isopoda (0.99) 
Table 2: Soil invertebrates' abundance in mature and young palm oil plot $(n=3)$

\begin{tabular}{lcc}
\hline $\begin{array}{l}\text { Soil invertebrates } \\
\text { (morphospecies) }\end{array}$ & \multicolumn{2}{c}{ Mean \pm SE } \\
\cline { 2 - 3 } & $\begin{array}{c}\text { Mature palm } \\
\text { oil plot }\end{array}$ & $\begin{array}{c}\text { Young palm } \\
\text { oil plot }\end{array}$ \\
\hline Annelida & $0.33 \pm 0.47$ & - \\
Arachnida & $15.00 \pm 9.09$ & $6.00 \pm 4.08$ \\
Blattodea & $1.33 \pm 1.25$ & - \\
Coleoptera & $8.00 \pm 7.87$ & $0.33 \pm 0.47$ \\
Diplura & $0.67 \pm 0.47$ & $0.33 \pm 0.47$ \\
Diptera & $1.00 \pm 1.41$ & - \\
Ephemerida & $1.67 \pm 0.94$ & - \\
Geophilomorpha & $0.67 \pm 0.47$ & - \\
Hemiptera & $0.67 \pm 0.94$ & - \\
Hymenoptera & $85.67 \pm 16.21$ & $53.67 \pm 7.93$ \\
Lepidoptera & $0.33 \pm 0.47$ & - \\
Isopoda & $1.33 \pm 0.47$ & $2.00 \pm 1.41$ \\
Odonata & $0.67 \pm 0.47$ & - \\
Orthoptera & $17.67 \pm 17.44$ & $8.00 \pm 8.49$ \\
Thysanoptera & $0.33 \pm 0.47$ & $0.33 \pm 0.47$ \\
Trichoptera & $0.67 \pm 0.94$ & $0.33 \pm 0.47$ \\
\hline
\end{tabular}

Table 3: Soil physical parameters and diversity in mature and palm oil plot $(n=3)$

\begin{tabular}{lcc}
\hline \multicolumn{1}{c}{$\begin{array}{c}\text { Soil physical } \\
\text { parameters \& } \\
\text { diversity indices }\end{array}$} & $\begin{array}{c}\text { Mature palm oil } \\
\text { plot }\end{array}$ & $\begin{array}{c}\text { Young palm } \\
\text { oil plot }\end{array}$ \\
\hline $\begin{array}{l}\text { Bulk density } \\
(\text { g/cm }\end{array}$ & $1.23 \pm 0.02$ & $1.25 \pm 0.03$ \\
Porosity $(\%)$ & $55.03 \pm 2.48$ & $51.81 \pm 1.31$ \\
Temperature $\left({ }^{\circ} \mathbf{C}\right)$ & $35.65 \pm 0.30$ & $37.36 \pm 0.10$ \\
Moisture (\%) & $34.05 \pm 0.60$ & $30.22 \pm 0.64$ \\
Shannon index & $0.54 \pm 0.03$ & $0.42 \pm 0.02$ \\
Evenness & $1.36 \pm 0.06$ & $0.81 \pm 0.09$ \\
Menhinick & $1.29 \pm 0.04$ & $0.84 \pm 0.03$ \\
\hline
\end{tabular}

whereas in young palm oil plot, soil moisture was strongly correlated with the abundance of Arachnida (0.90) and Hymenoptera (0.97). High value of Pearson correlation coefficients indicates strong influence of physical soil properties on the abundance of soil invertebrates.

\subsection{Functional group}

Soil invertebrates were divided according to size and functional groups (Lavelle et al., 1996) (Table 5). The first size group is the microfauna with a size of less than $0.2 \mathrm{~mm}$. However, no microfauna was found in this study. The second size group is the mesofauna (0.2 -2.0 mm) which consists of Arachnida and Diplura. Thirdly is the macrofauna with a size of more than $2.0 \mathrm{~mm}$ which comprises of Annelida, Blattodea, Coleoptera, Diptera, Ephemerida, Geophilomorpha, Hemiptera, Hymenoptera, Lepidoptera, Isopoda, Odonata, Orthoptera, Thysanoptera, and Trichoptera. The functional groups were categorized into three which are predators, litter transformers, and ecosystem engineers. Arachnida, Hymenoptera, Geophilomorpha, Coleoptera, and small Annelida were grouped in the predator functional group which play roles in nutrient cycling and regulation of bacterial population. Additionally, Diplura and small Annelida were grouped in the litter transformers which contributes to the sequestration of organic material, fragmentation of residues, and humification.

Annelida and Hymenoptera were classified as ecosystem engineers which are mostly involved in carbon sequestration, bioturbation, and maintenance of structural porosity (Table 5). Based on Figure 1, the mature palm oil plot recorded $58.13 \%$ macrofauna while the young palm oil plot recorded $31.24 \%$. For mesofauna, mature palm oil plot recorded $7.57 \%$ and young palm oil with $3.06 \%$. As for the functional group, mature palm oil plot recorded $41.55 \%, 0.48 \%$, and $52.98 \%$ for ecosystem engineer, litter transformer, and predator respectively whereas young palm oil plot recorded $25.93 \%, 0.16 \%$, and $28.99 \%$ for ecosystem engineer, litter transformer and predator respectively.

\section{Discussion}

Findings suggest that a mature palm oil plot is more hospitable to several diverse soil invertebrates in comparison to a young palm oil plot. It is typically discovered that communities inhabiting undisturbed or moderately disturbed habitat were greater and more diversified than those inhabiting persistently disturbed sites that experience changes in structure and texture, as well as being exposed to fertilizers, and applications of pesticides and herbicides (Prashar and Shah, 2016). Microclimate affects many vital ecological systems, such as plant development and the cycling of soil nutrients (Bonan, 2008). The microclimate in palm oil plots is inclined to be hotter and drier than that of forested regions (Turner and Foster, 2006), thus creating more stressful environmental conditions and consequently resulting in alterations in community structure (Fayle et al., 2010). According to Ashcroft and Gollan 
Table 4: Pearson correlation coefficients between physical soil properties and soil invertebrate's abundance in mature and young palm oil plot

\begin{tabular}{|c|c|c|c|c|}
\hline & $\begin{array}{c}\text { Bulk } \\
\text { density }\end{array}$ & Porosity & Temperature & Moisture \\
\hline \multicolumn{5}{|l|}{ Annelida } \\
\hline Arachnida & $0.97 *$ & $\begin{array}{l}0.63^{*} \\
0.96^{*}\end{array}$ & $\begin{array}{l}0.26^{*} \\
0.69^{*}\end{array}$ & $\begin{array}{l}0.90 * \\
0.82 *\end{array}$ \\
\hline Blattodea & & & $0.73 *$ & \\
\hline Coleoptera & & & $0.84^{*}$ & $0.42 *$ \\
\hline Diplura & $0.66^{*}$ & & $0.81 *$ & \\
\hline Diptera & & & $0.92 *$ & \\
\hline Ephemerida & & & $0.92 *$ & \\
\hline Geophilomorpha & & & 0.11 & \\
\hline \multicolumn{5}{|l|}{ Hemiptera } \\
\hline Hymenontera & $0.62 *$ & $0.98^{*}$ & & $0.82 *$ \\
\hline пупетортега & $0.61^{*}$ & $0.85 *$ & & $0.97 *$ \\
\hline \multicolumn{5}{|l|}{ Lepidoptera } \\
\hline Isopoda & $0.98^{*}$ & $0.87 *$ & & $0.99 *$ \\
\hline Odonata & $0.66^{*}$ & & $0.81 *$ & $0.42 *$ \\
\hline Orthoptera & & $0.29 *$ & & $0.57 *$ \\
\hline Thysanoptera & $0.90 *$ & $0.69 *$ & $0.96 *$ & $0.43 *$ \\
\hline Trichoptera & & $0.29 *$ & & $0.57 *$ \\
\hline
\end{tabular}

Significant correlations $(\mathbf{p}<0.05)$ are indicated by *

(2012), canopy cover possesses a critical effect in an positive influence of soil cover on soil invertebrate's extreme environment. Oil palm plantations in abundance and nutrient supply were also reported by Southeast Asia have been recorded to be $2.8^{\circ} \mathrm{C}$ hotter Tian et al., 1997.

and substantially less humid than the surrounding forest during the day (Luskin and Potts, 2011). Apart from being reduced in diversity at the taxonomic degree, oil palm plantations are also architecturally much simpler than natural forests, with reduced canopy layers and reduced components like litter, lianas, and epiphytes (Foster et al., 2011).

The variety of highly diverse plant cover in mature palm oil plot that enhanced the quality of organic matter produced and soil water and temperature system is the reason for greater diversity in this community. From this study, mature palm oil palm has a fully developed canopy, good soil cover, and many piles of cut fronds which provide an adequate shelter for soil microorganisms. Palm fronds serve as a refuge for insects as its temperature is slightly lower and its condition is not bright. Thus, the mature palm Furthermore, palm trees are large and long-lived

oil plot recorded higher fauna composition and which results in heterogeneity and a longer time diversity of soil invertebrate's community. The

In contrast, the young palm oil plot has a developing canopy thus the soil underneath is partially sheltered and some are exposed resulting in a lack of a place of refuge for soil invertebrates. This explains the reason why the young palm oil farm recorded a higher soil temperature with a value of $37.26^{\circ} \mathrm{C}$ whereas the soil temperature in the mature palm oil farm was $36.04^{\circ} \mathrm{C}$. In regards to that, mature palm oil farms recorded higher soil moisture with a mean value of $33.56 \%$ and young palm oil farms with $30.74 \%$. Besides that, the young palm oil farm has recorded a higher average value of bulk density $(1.29 \mathrm{~g} / \mathrm{cm} 3)$ which may cause its soil to be slightly more compact thus resulting in a lack of organic matter and nutrient deficiency (Yeboua and Ballo, 2000). 
for a sophisticated composition of species to be produced (Mariau, 2001). The presence of smaller vegetations may provide some sort of intricacy and there is a possibility for a comparatively diverse epiphytes assemblage which may promptly grow on the trunks of the oil palm trees. Half of the epiphytes species of lowland regions have

been documented from oil palm estates in west Malaysia (Foster et al., 2011). Moreover, understory vegetation which is plentiful in mature palm oil plot may also be essential in creating a vast number of leaf litter in the oil palm plantations, which itself encourages and boost an enhanced diversity and taxa abundance (Chung et al., 2000). Ferns which are abundant in mature palm oil plot can buffer microclimate, as the temperature influence ant communities in the canopy and leaf litter (Fayle et al., 2010).

Moreover, the lack of canopy cover in young palm oil plots creates a hostile environment which may hinder the dispersal of soil invertebrates due to hotter and drier conditions (Gay et al., 2016). Thus, because of its stable habitat and balanced ecosystem created by the ideal temperature under the canopy, and the presence of a stack of palm fronds which provide refuge for soil invertebrates, mature palm oil plot recorded the greatest abundance and diversity of soil invertebrates. As the young oil palm canopy is biologically simpler, more exposed, and lower than that of the closed-canopy rainforest, the temperature and humidity are much more difficult for most soil fauna (Foster et al., 2011). Diversity differences between the two plots reflect the ecosystem stability in mature palm oil plot. Marginally lower temperature as a result of full canopy shelter in mature palm oil plot offers plenty of refuges which provide safety against predator and more food supply than young palm oil plot.

Additionally, young palm oil plot has received fertilizer, herbicide, and pesticides periodically whereas soil in mature palm oil plot is essentially undisturbed, clear from farming activities such as soil tilling, and application of herbicide and pesticide which are the most presumed mediums impacting diversity besides land disturbance (Menta, 2012). Macrofauna recorded the greatest abundance of soil invertebrates in both sites. This high number is associated with Hymenoptera, which have strong influence on the constitution of the faunal communities as they have greater dispersal capacity in different habitats (Mateos et al., 2011) (Figure 1). Similar findings have also been reported by Maqtan et al., 2018 in which cultivated fields have recorded a lower number of soil organisms and diversity compared to uncultivated land.

Findings from this study bring sufficient evidence about the ecological importance of litter transformers (Diplura, small Annelida) and ecosystem engineers (Hymenoptera and Annelida) in both mature and young palm oil plots (Table 5). Hymenoptera (ants) are the most prevalent as their functional groups

Table 5: Classification of soil invertebrates according to their size and function (Lavelle et al., 1996) and (Cardoso et al., 2013).

\begin{tabular}{|c|c|c|c|}
\hline & & Morphospecies & Functions \\
\hline \multirow[t]{2}{*}{ Size group } & $\begin{array}{l}\text { Macrofauna } \\
(>2.0 \mathrm{~mm})\end{array}$ & $\begin{array}{l}\text { Annelida, Blattodea, Coleoptera } \\
\text { Diptera, Ephemerida, } \\
\text { Geophilomorpha, Hemiptera, } \\
\text { Hymenoptera, Lepidoptera } \\
\text { Isopoda, Odonata, Orthoptera } \\
\text { Thysanoptera, Trichoptera }\end{array}$ & 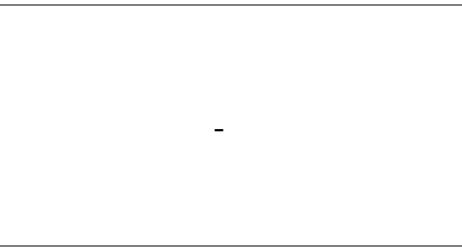 \\
\hline & $\begin{array}{l}\text { Mesofauna } \\
(0.2-2.0 \mathrm{~mm})\end{array}$ & Arachnida, Diplura & - \\
\hline \multirow{3}{*}{ Functional group } & $\begin{array}{l}\text { Ecosystem } \\
\text { engineer }\end{array}$ & Annelida, Hymenoptera & $\begin{array}{ll}\text { - } & \text { Bioturbation } \\
\text { - } & \text { Regulation of structural } \\
& \text { porosity } \\
\text { - } & \text { Water storage capacity } \\
\text { - } & \text { Stimulate microbial activity } \\
\text { - } & \text { Carbon sequestration } \\
\end{array}$ \\
\hline & $\begin{array}{l}\text { Litter } \\
\text { transformer }\end{array}$ & Diplura, small Annelida & $\begin{array}{ll}\text { - } & \text { Soil aggregation/bio pores } \\
\text { - } & \text { Sequestration of organic } \\
\text { material } \\
\text { - } & \text { Fragmentation of residues } \\
\text { - } & \text { Humification } \\
\end{array}$ \\
\hline & Predators & $\begin{array}{l}\text { Arachnida, Hymenoptera, } \\
\text { Geophilomorpha, Coleoptera, small } \\
\text { Annelida }\end{array}$ & $\begin{array}{ll}\text { - } & \text { Nutrient cycling, } \\
\text { mineralization } \\
\text { - } \\
\text { Regulate bacterial/fungal } \\
\text { population }\end{array}$ \\
\hline
\end{tabular}


exhibit more varying relation, with some being mature palm oil plot has exhibited more fauna (16 opportunistic insects and behaviorally dominant morphospecies) composition than the young palm oil groups being more prolific in degenerated habitat (Luke et al., 2014). Ants may be omnivorous, opportunistic feeders, or herbivores but mostly they are predators of invertebrates (Hölldobler and Wilson, 1994). The functional significance of ground-dwelling ants in the activity of nutrient cycling because of their duty in bioturbation and enrichment of microbial activity (Dauber and Wolters, 2000) signified their role as engineers of the ecosystem (Jones et al., 1994). Ants are one of the most significant soil dwellers as they are accountable for ecosystem tasks namely collection and dispersal of seeds, fragmentation of litter, nutrient cycling, vegetation cropping, and control of other groups of soil organisms such as termites, (Shukla et al., 2013).

Also, Orthoptera which includes grasshoppers and crickets indicates ecological modification and the impacts of habitat management (Jonas et al., 2002). Orthoptera may also be vulnerable to pollution ( $\mathrm{Li}$ et al., 2005). Apart from that, grasshoppers also have good potential to be explored as they are found to be highly sensitive to changes grassland environment (Chambers and Samways, 1998). Grasshoppers are especially associated with butterflies and are used as indicators of environmental modification in South Africa (Bazelet and Samways, 2011).

Furthermore, spiders (Arachnida) have been applied as indicators in some places. They are diverse, and several families are recognizable and are comparatively easy to identify, albeit most families are taxonomically inconsistent and challenging to identify (Gerlach et al., 2013). Spiders have been employed as indicators of particular habitat properties (Buchholz, 2010) or habitat alteration (Magura et al., 2010). Indication for habitat control (Cardoso et al., 2004) and habitat rehabilitation (Gollan et al., 2010) has also been recorded. As predators, spiders accumulate pesticides and pollutants from their prey thus they may be employed as ecological accumulators to specify degrees of environmental toxin (Seyyar et al., 2010).

\section{Conclusion}

Soil invertebrates' abundance and diversity depend on land use practice. A mature palm oil plot favored the abundance and diversity of soil fauna. Shannon-Wiener index value showed a high diversity of soil invertebrates in mature palm oil plot. The plot (8 morphospecies). A disturbed environment with heavy use of agrochemicals may alter the abundance and diversity of soil invertebrate community in the soil. These invertebrates play important biological processes in the ecosystem such as stimulation of microbial activity, nutrient cycling, regulation of bacterial or fungal population, and carbon sequestration. Employing functional species as bioindicators of soil health has been preferred due to the role they play in biological systems. Indeed, soil health is the primary necessity to achieve both environmental and agricultural sustainability.

Management of oil palm plantations may be carried out by seeding, planting, harvesting, and clearing. Good management of these plantations can be achieved by taking into account the selection of land, planting materials, technical management, and harvesting techniques. If it is monitored well and properly executed, then this may enhance the productivity of palm oil and the efficiency of work as well as financing. The challenge is to create an improved utilization of the diversity and elasticity of the soil biological community to sustain a balanced ecosystem, thus promoting environmental sustainability. The discovery for self-sustaining, lesser-input, modified, and energy-saving agricultural systems is now a great agitation of many researchers, scientists, farmers, and policymakers all over the globe. A fundamental procedure in sustainable agriculture is to reestablish the practical biodiversity of the agricultural aspect. If properly constructed, biodiversity can create agroecosystems competent in supporting their soil fertility, crop security, and yield.

\section{Recommendations}

Based on the result of this study it is worth to recommend the following points:

- Activity on the soil layer that may affect the existence and survival of soil invertebrates should be considered. Thus, due attention should be given to enhance the presence of invertebrates because of their significance in sustaining life.

- Besides other known ecological functions of the palm oil farms, the palm oil farms should be given special emphasis for their biodiversity as it may contribute to carbon sequestration which is a global issue. 
- The consequence of transforming natural forests to oil palm farms should be assessed for its negative impacts.

\section{Acknowledgements}

We would like to thank Universiti Putra Malaysia for providing the facilities to conduct this research. Special thanks to field assistants for their help during the sampling.

\section{References}

Ashcroft, M. B., Gollan, J. R. (2012). Fineresolution $(25 \mathrm{~m})$ top climatic grids of near-surface $(5$ $\mathrm{cm})$ extreme temperatures and humidities across various habitats in a large $(200 \times 300 \mathrm{~km}) \quad$ and diverse region. Int J Climato. 32 (14): 2134-2148.

Barnes, A.D., Jochum, M., Mumme, S., Haneda, N.F., Farajallah, A., Widarto, T.H., Brose, U. (2014). Consequences of tropical land-use for multitrophic biodiversity and ecosystem functioning. Nat. Commun. 5(5351): 1-7.

Bazelet, C., Samways, M.J. (2011). Identifying grasshopper bioindicators for habitat quality assessment of ecological networks. Ecol. Indic. 11(5):1259-1269.

Bonan, G.B. (2008). Forests and climate change: Forcings, feedbacks, and the climate benefits of forests. Science. 320 (5882): 1444-1449.

Buchholz, S. (2010). Ground spider assemblages as indicators for habitat structure in inland sand ecosystems. Biodivers Conserv. 19(9): 2565-2595.

Cardoso, E.J.B.N, Vasconcellos, R.L.F., Bini, D., Miyauchi, Y.H., Santos, C.A., Alves, P.R.L.,

Paula, A.M., Nakatani, A.S., Pereira, J.M.P., Nogueira, M.A. (2013). Soil health: looking for suitable indicators. What should be considered to assess the effects of use and management on soil health? J. Agric. Sci. 70 (4): 274-289.

Cardoso, P., Silva, I., de Oliveira, N.G., Serrano, A.R.M. (2004). Indicator taxa of spider (Araneae) diversity and $\mathrm{m}$ their $\mathrm{m}$ efficiency in conservation. Biodivers Conserv. 120 (4):517-524.

Çakır, M., Makineci, E. (2018). Community structure and seasonal variations of soil microarthropods during environmental changes. Appl Soil Ecol. 123: 313-317.
Chambers, B.G., Samways, M.J. (1998). Grasshopper response to a 40-year experimental burning and mowing regime, with recommendations for invertebrate conservation management. Biodivers Conserv. 7(8): 985-1012.

Chen, G. Zhu, H., Zhang, Y. (2003). Soil activities and carbon and nitrogen fixation. Microbiol. Res. 154(6): 393-398.

Chung, A.Y.C., Eggleton, P., Speight, M.R., Hammond, P.M., Chey, V.K. (2000). The diversity of beetle assemblages in different habitat types in Sabah, Malaysia. Bull Entomol Res, 90(6): 475-496.

Climate-Data.org. (2019). Mardi Serdang Climate. Retrieved from

https://en.climatedata.org/asia/malaysia/

selangor/mardi-serdang-971613/

Dauber J., Wolters V. (2000). Microbial activity and functional diversity in the mounds of three different ant species. Soil Biol Biochem, 32: 93-99.

Fayle, T.M., Turner, E.C., Snadonn, J.K, Chey, V.K., Chung, A.Y.C., Eggleton, P., Foster, W.A. (2010). Oil palm expansion into rain forest greatly reduces ant biodiversity in canopy, epiphytes and leaf-litter. Basic Appl Ecol., 11: 33-35.

Foster, W.A., Snaddon, J.K., Turner, E.C., Fayle, M., Cockerill, T.D., Ellwood, M.D.F., Broad, G.R., Chung, A.Y.C., Eggleton, P., Khen, C.V., Yusah, K.M. (2011). Establishing the evidence base for maintaining biodiversity and ecosystem function in the oil palm landscapes of South East Asia. Philos Trans R Soc Lond B Biol Sci, 366 (1582): $3277-3291$.

Gay, A., Cerdan, O., Mardhel, V., Desmet, M. (2016). Application of an index of sediment connectivity in a lowland area. J Soil Sediment., 16 (1): 280-293.

Gerlach, J., Samways, M., Pryke, J. (2013). Terrestrial invertebrates as bioindicators: an overview of available taxonomic groups. J Insect Conserv., 17(4): 831-850.

Gollan, J.R., Smith, H.M., Bulbert, M., Donnelly, A.P., Wilkie, L. 2010. Using spider-web types 
as a substitute for assessing web-building spider postfire management of a Mediterranean biodiversity and the success of habitat Hymenoptera community. Environ Manage, 48(5): restoration. Biodivers Conserv., 19 (11): 3141- 3155. 1000-1012.

Hölldobler, B., Wilson, E.O. (1994). Journey to the Mariau, D. (2001). The fauna of oil palm and ants: a story of scientific exploration. Harvard coconut: insect and mite pests and their natural University Press, Cambridge, Massachusetts, and enemies. Cirad. Montpellier, 249.

London: 1994. Pp 224:94

Jonas, J., Whiles. M., Charlton, R. (2002). Above Karam, D.S. (2018). Morphospecies m diversity of ground invertebrate responses to land management soil invertebrates in cultivated and uncultivated fields. differences in central Kansas grassland. Environ J.Biosci.Appl.Res. 4(4): 507-518.

Entomol. 31(6):1142-1152. Jones, C. G., Lawton, J. H., Shachak, M. (1994). Soil Degradation, Biological Indices, Soil Restoration, Organisms as ecosystem engineers. Oikos, 69(3): Biodiversity Conservation and Utilization in a 373-386.

Diverse World, Dr. Gbolagade Akeem Lameed (Ed.), InTech, DOI: 10.5772/51091.

Kaschuk, G., Alberton, O., Hungria, M. (2010). Three decades of soil microbial biomass studies in Brazilian ecosystems: lessons learned about soil quality and indications for improving sustainability. Soil Biol. Biochem 42: 1-13.

Neto, E.S., Carmo, J.B., Keller, M., Martins, S.C., Alves, L.F., Vieira, S.A., Piccolo, M.C., Carmargo, P., Couto, H.T.Z., Joly, C.A., Martinelli, L.A. (2011). Soil- atmosphere exchange of nitrous oxide, methane and carbon dioxide in a

Lavelle P. (1996). Diversity of soil fauna and ecosystem function. Int. J. Biol, 33:3-16.

Luke, S.H., Fayle, T.M., Eggleton, P. 2014. Functional structure of ant and termite assemblages in old-growth forest, logged forest and oil palm plantation in Malaysian Borneo. Biodivers Conserv. 23(11): 2817-2832.

Li, L.J, Liu, X.M, Guo, Y.P., Ma, E.B. (2005). Activity of the enzymes of the antioxidative system in cadmium-treated Oxya chinensis (Orthoptera: Acridoidae). Environmental Toxicology and Pharmacology, 20(3): 412-416.

Ludwig, J. A., Reynolds, J. F. (1988). Statistical Ecology - A Primer on Methods and Computing. Wiley, New York.

Luskin, M.S., Potts, M.D. (2011). Microclimate and habitat heterogeneity through the oil palm lifecycle. Basic Appl Ecol.12: 540-551.

gradient of elevation in the coastal Brazilian Atlantic forest. Biogeosciences Discussions, 8(3): 733-742

Prashar, P., Shah, S. (2016). Impact of fertilizers and pesticides on soil microflora in agriculture. E. Lichtfouse (Ed.), Sustainable Agriculture Reviews: vol. 19, Springer International Publishing, Cham, pp. 331-361.

Sahu, H., Obi, Reddy, G.P.O., Kumar, N., Nagaraju, M.S.S. (2015). High resolution remote sensing, GPS and GIS in soil resource mapping and characterization- A Review. Agriculture Review, 36 (1): $14-25$.

Santorufo, L., Van Gestel, C.A., Rocco, A., Maisto, G. (2012). Soil invertebrates as bioindicators of urban soil quality. Environ Pollut. 161:57-63.

Savilaakso, S., Garcia, C., Garcia-Ulloa, J., Ghazoul, J., Groom, M., Guariguata, M.R., Laumonier, Y., Nasi, R., Petrokofsky, G., Snaddon, Magura, T., Horvath, R., Tothmeresz, B. (2010). J., Zrust, M. (2014). Systematic review of effects on Effects of urbanization on ground- dwelling spiders in biodiversity from oil palm production. Environ E. forest patches, in Hungary. Landsc. Ecol, 259(4):621- 3(4): 2-20. 629.

Seyyar, O., Demir, H., Aktaş, M. (2010). A new Mateos, E., Santos, X., Pujade-Villar, J. (2011). species and two new records of the genus Zelotes Taxonomic and functional responses to fire and Gistel, 1848 (Araneae: Gnaphosidae) from Turkey. 
Arch. Biol. Sci, 62 (2): 449- 453.

Shannon C.E., Weaver W. (1949).The mathematical theory of information. Urbana, IL: The University of Illinois Press, 1-117. Shukla, R.K., Singh, H., Rastogi, N., Agarwal, V.M. (2013). Impact of abundant Pheidole ant species on soil nutrients in relation to the food biology of the species. Appl Soil Ecol. 71:15-23.

Shukla, R.K., Singh, H., Rastogi, N., Agarwal, V.M. (2013). Impact of abundant Pheidole ant species on soil nutrients in relation to the food biology of the species. Appl Soil Ecol. 71:15-23.

Thyssen, P.J. (2010). Keys for identification of immature insects. In: Amendt J, Campobasso, C.P., Goff, M.L. and Grassberger, M. (Eds), editor. Current concepts in Forensic Entomology: Springer. 25-42.

Tian G., Kang, B.T., Brusaard, L. (1997). Effect of mulch quality on earthworm activity and nutrient supply in the humid tropics. Soil Biol Biochem. 29

(3-4):369-373.

Turner, E. C., Foster, W. A. (2006). Assessing the influence of bird's nest ferns (Asplenium spp.) on the local microclimate across a range of habitat disturbances in Sabah, Malaysia. Selbyana, 27(2): 195-200.

Whittaker, R.H. (1977). Evolution of species diversity inland communities. In: Hecht, M.K. and Steere, B.W.N.C. Eds. Evol Biol, Plenum Press, New York, 1-67.

Wich, S.A., Garcia-Ulloa, J., Kühl, H.S., Humle, T., Lee, J.S.H., Koh, L.P. (2014). Will oil palm's homecoming spell doom for Africa's great apes? Curr
Biol. 24(14): 1659-1663.

Yeboua, K., Ballo, K. (2000). Caracte'ristiques chimiques du sol sous palmeraie. Cahiers d'e'tudes et de recherches francophones. Agricultures. 9:73-76.

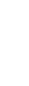


Figure 1: The different percentage composition of invertebrate's groups between the two sites

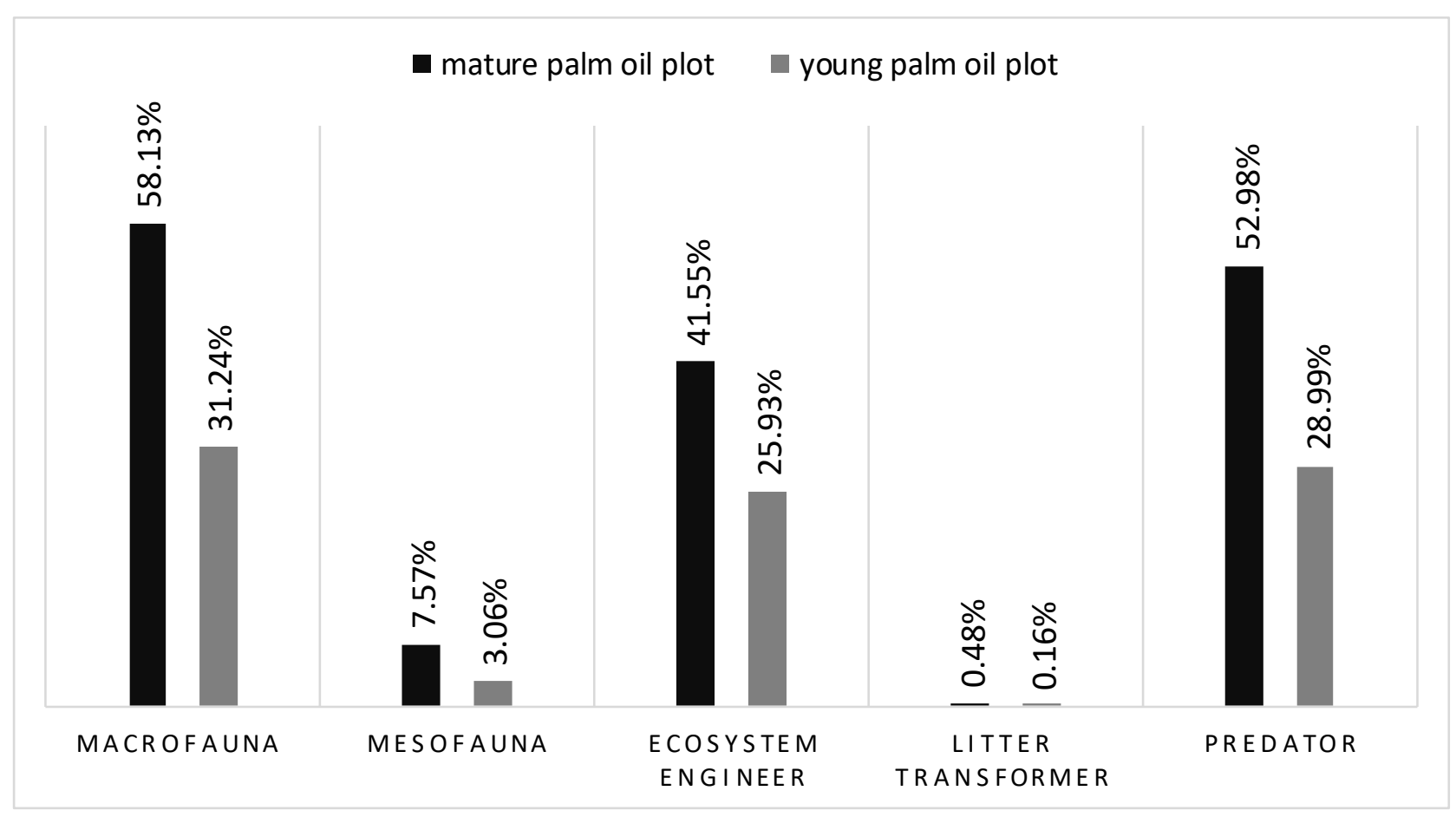

